\title{
Giant Condyloma Acuminatum in a Woman with AIDS
}

\author{
Kondiloma Akuminata Raksasa pada Perempuan dengan AIDS
}

\author{
Laila Nuranna, Tricia D. Anggraeni, Tofan W. Utami, Denny Khusen \\ Division of Oncology Gynecology \\ Department of Obstetrics and Gynecology \\ Faculty of Medicine University of Indonesia/ \\ Dr. Cipto Mangunkusumo Hospital \\ Jakarta
}

\begin{abstract}
Objective: To describe a case of Giant Condyloma Acuminatum with aspect of HIV and some concerns about the CD4.

Result: We describe 2 cases, the first case is a giant Condyloma in HIV patient and the second case is a giant Condyloma in pregnant woman. The patient in the first case was a 40-year-old woman with AIDS (CD4 is 290) who was undergoing anti-retroviral therapy. She was found to have a giant condyloma acuminatum of the vulva. Electrocautery excision was performed, and afterwards the quality of life has improved significantly. The second case patient is a 30-year-old $\mathrm{G}_{4} \mathrm{P}_{3} \mathrm{~A}_{0}$ woman with a giant condyloma acuminatum. She was 30 weeks pregnant with a single fetus. On the external genitalia there was a giant condyloma mass on the vulva extending towards the peri-anal area, obstructing the introitus. The electrocautery excision was performed. She was discharged from the hospital on the second day in good condition. She had a spontaneous delivery after reaching full term.
\end{abstract}

Conclusion: Although the giant Condyloma Acuminatum is combined with HIV, but it's not as difficult as imagined because the tumor's base is not wide, but shaped like inverted mushroom and it is not necessary to do local flap reconstruction.

[Indones J Obstet Gynecol 2012; 36-4: 206-10]

Keywords: electrocautery excision, giant condyloma acuminatum, surgery in AIDS

\begin{abstract}
Abstrak
Tujuan: Untuk menggambarkan kasus Kondiloma Akuminata Raksasa dengan aspek HIV dan beberapa kekhawatiran mengenai $\mathrm{CD}_{4}$.

Hasil: Kami menjelaskan 2 kasus, kasus pertama adalah Kondiloma raksasa pada pasien HIV dan kasus kedua adalah kondiloma raksasa pada perempuan hamil. Pasien kasus pertama adalah seorang perempuan 40 tahun dengan AIDS $\left(C D_{4}=290\right)$ yang menjalani terapi antiretroviral Pasien ditemukan memiliki kondiloma akuminata raksasa pada vulva. Eksisi elektrokauter dilakukan, setelah itu kualitas hidupnya meningkat secara signifikan. Pasien kasus kedua adalah seorang perempuan 30 tahun $\mathrm{G}_{4} \mathrm{P}_{3} \mathrm{~A}_{0}$ dengan kondiloma akuminata raksasa, pasien hamil 30 minggu dengan janin tunggal. Pada alat kelamin eksternal tampak massa kondiloma raksasa di vulva menyebar menuju daerah perianal menghalangi daerah introitus. Eksisi elektrokauter dilakukan. Pasien keluar dari rumah sakit pada hari kedua dalam kondisi baik dan ia mampu melahirkan spontan aterm.

Kesimpulan: Meskipun dalam kasus ini kondiloma akuminata raksasa disertai dengan HIV, tapi tidak sesulit yang dibayangkan karena basis tumor tidak lebar, tapi berbentuk seperti jamur terbalik dan tidak perlu dilakukan rekonstruksi flap lokal.

[Maj Obstet Ginekol Indones 2012; 36-4: 206-10]
\end{abstract}

Kata kunci: bedah dalam AIDS, eksisi elektrokauter, kondiloma akuminata raksasa

Correspondence: Laila Nuranna, Department of Obstetrics and Gynecology, Medical Faculty of Indonesia University, Salemba Raya 6, Jakarta 10430 - Indonesia. Tel: +62-21-3914806, E-mail: lailaril@yahoo.com

\section{INTRODUCTION}

Giant condyloma acuminatum (GCA) was first identified by Buschke and Loewenstein in 1925 as penile condyloma which resembles carcinoma without true microscopic invasion findings. ${ }^{1,2}$ The term giant condyloma for Buschke-Löwenstein tumor is considered to be synonymous to verrucous carcinoma. $^{3-6}$ Although it is mostly localized on glans penis and its surroundings, it may also appear in vulva and anorectal regions. ${ }^{1-6}$ In some other cases, it is localized in endocervix, lower uterine segment, bladder, prostate, urethra and a chronic pilonidal sinus. ${ }^{7,8}$
This slow-growing, locally destructive tumor of the ano-genital region is thought to be induced by human papillomavirus (hPV), most commonly hPV types 6 and 11 and occasionally types 16 and 18 . It is associated with extensive local infiltration and a high propensity to recur. Most authors consider it to be a verrucous carcinoma, a variant of squamous cell carcinoma that seldom metastasizes. ${ }^{2,9}$ Histological examination, however, may reveal pockets of squamous cell carcinoma, a risk factor for metastasis. It is histologically benign, but may become malignant clinically. ${ }^{1,2}$ Giant condyloma acuminatum affects in the vulva, vagina, cervix uteri, the peri-anal region, ano-rectum, penis and the blad- 
der. ${ }^{10}$ Ano-genital condylomata acuminatum or warts are common lesions in patients with HIV, but giant condyloma acuminatum or Buschke-Löwenstein tumors in patients with HIV are very rare. ${ }^{11,12}$

Condylomas are wart-like growths around the anus, vulva, or tip of the penis. These warts typically develop in the perianal region of HIV patients who have the human papillomavirus (hPV). The warts may be flat or cauliflower shaped. Small warts may spontaneously resolve. Lesions can be removed at a doctor's office either by means of a scalpel, electrosurgery, laser ablation, or liquid nitrogen. While these procedures have been shown to be safe, warts removal surgery on AIDS patient does not cure the virus or prevent future outbreaks. ${ }^{13}$

In this report, we describe 2 cases, the first case is a giant Condyloma in HIV patient and the second case is a giant Condyloma in pregnant woman.

\section{Case 1.}

The $1^{\text {st }}$ case is a 40-year-old Indonesian woman with AIDS undergoing anti-retroviral (ARV) therapy and monitored her $\mathrm{CD}_{4}$ level, who presented to our hospital with a giant condyloma acuminatum lesion. She first noted the lesion one year prior to her presentation to our institution. The mass had grown slowly over the months, with ulceration associated with foul-smelling discharge (Figure 1). She had been diagnosed with HIV, and ARV therapy had been started two years prior to the development of the vulva mass. She also had the wasting syndrome, an AIDS-defining diagnosis. She was married, but her husband died a year ago due to HIV exposure.

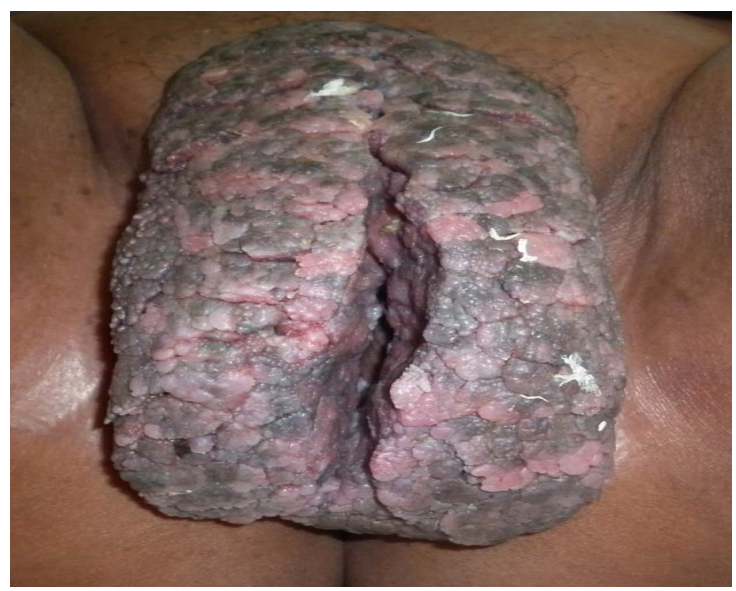

Figure 1. Giant condyloma acuminatum of the vulva.

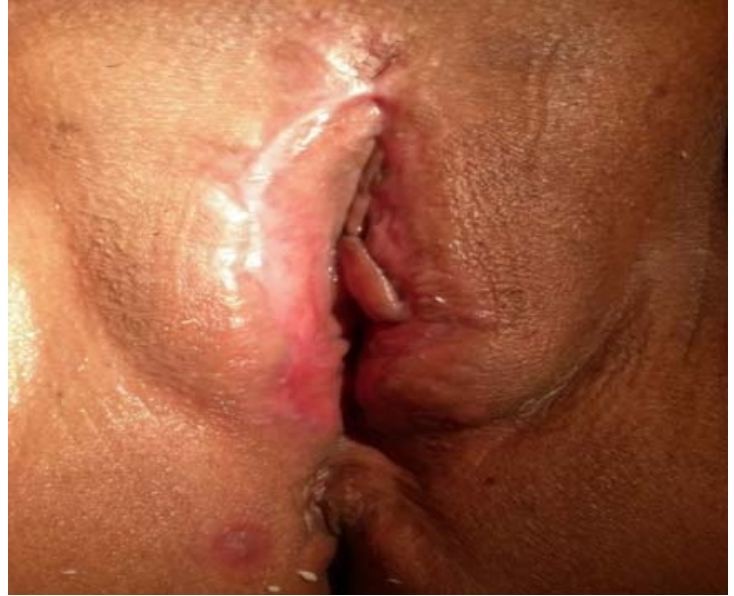

Figure 2. One and a half months post excision cauterization of giant condyloma.

The patient's physical examination revealed that she was emaciated. She had a large vulva mass that extended superiorly into the supra-pubic region and posteriorly to the anal verge.

Her hemoglobin level was $10.7 \mathrm{~g} / \mathrm{dl}$ and her $\mathrm{CD}_{4}$ lymphocyte count was 290 cells $/ \mathrm{mm}^{3}$. During surgery, the tumor was found to have extended laterally into the adductor musculature bilaterally, requiring their inclusion in the excision. The deep margins included the rectus muscle fascia, pubis, pelvic diaphragm, and rectum. A small part of the bulbous urethra was excised with the tumor. The electrocautery excision was done to remove the tumor. The excised tumor weighed $900 \mathrm{~g}$ and was reported on the basis of a histological examination to be a giant condyloma acuminatum. After one and a half months, her wounds were healed and the result of anatomic pathology is a giant condyloma acuminatum (Figure 2).

One important thing to know regarding her quality of life is the fact that this patient goes to work by motorbike everyday. But because of this tumor, the patient felt very uncomfortable while riding a motorbike. Now, after surgery, the patient can ride a motorbike more conveniently.

\section{Case 2.}

A 30-year-old $\mathrm{G}_{4} \mathrm{P}_{3} \mathrm{~A}_{0}$ woman with a giant condyloma acuminatum was referred to the Gynecological Clinic. She had a history of abnormal growth on genitalia since 6 months prior to admission. The mass was growing slowly and not associated with pain or itching. The patient occasionally had abnormal vaginal discharges which she described as foul 


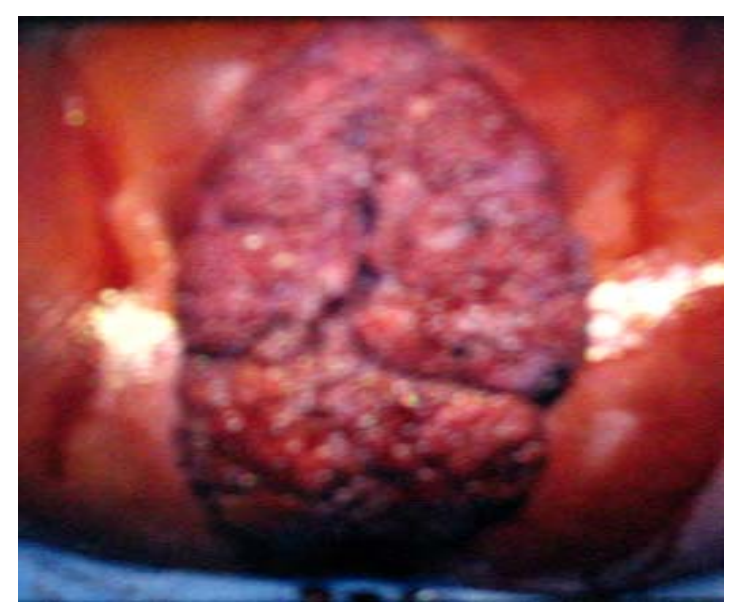

Figure 3. Giant condyloma acuminatum of the vulva.

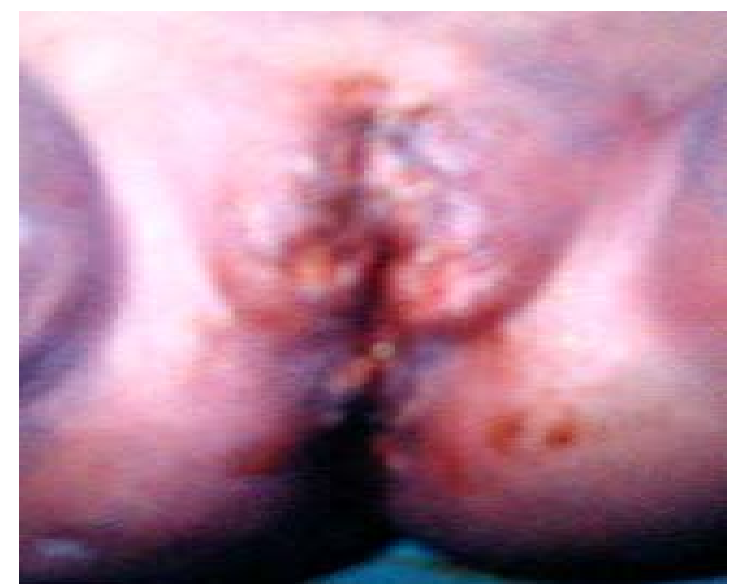

Figure 4. One month post excision cauterization of giant condyloma.

smelling. She lived with her husband, children, and other family members with no history of skin or genital warts.

She was 30 weeks pregnant with a single fetus; on physical examination, the patient was found to be a lean female with an overall good condition. On inspection of the external genitalia it was found that there was a giant condyloma mass on the vulva extending towards the peri-anal area obstructing the introitus (Figure 3).

The electrocautery excision was done to remove the tumor. There was no involvement of condyloma at the cervix or vagina. She was discharged from the hospital on the second day in good condition.

After one month, her wounds were healed and the result of anatomic pathology show a giant condyloma acuminatum (Figure 4). On examination of the patient's external genitalia, there were no recurrent lesions and she had spontaneous delivery after reaching full term pregnancy.

\section{DISCUSSION}

Condyloma with large lesions can be classified as giant Condyloma. Googe et al classified condyloma acuminatum with a diameter $>2.5 \mathrm{~cm}$ as a giant Condyloma. ${ }^{14}$ Giant condyloma acuminatum generally occurs in adults, but has also been reported in children. Poor hygiene is a known predisposing factor, while chronic inflammation (peri-anal fistuli), immunosuppression (HIV or therapy), diabetes, pregnancy, poor socioeconomic status, and smoking are recognized as risk factors. ${ }^{15}$

The $1^{\text {st }}$ case presented here was an immunosuppressed patients, with a HIV infection and $\mathrm{CD}_{4}$ is 290, despite having been on ARVs for a long period. Immunosuppression, HIV infection coexistence, irritant effects of long-term anal sex and unhygienic conditions are not only the risk factors in the development of GCA but also play a role in malignant transformation. ${ }^{1,2}$ Although immunosuppression is a recognized risk factor, giant condyloma acuminatum on patients suffering HIV/AIDS and receiving ARV therapy is extremely rare. How radical should surgical extirpation be? How aggressive should any adjuvant therapy be? The use of ARVs and immunosuppressants and/or immunomodulators is established in the care of renal transplant patients with HIV infection. A meta-analysis by Landin et al of 12 series of reports of HIV-positive recipients under highly active antiretroviral therapy (HAART) receiving kidney transplants reported the development of an AIDS-defining tumor in a single patient. A conclusion of this meta-analysis was that renal transplantation, and therefore the use of immunosuppressive therapy, is safe in patients with HIV undergoing HAART. ${ }^{16}$

The rare causes of giant condyloma acuminatum in patients with HIV/AIDS is puzzling, considering that hPV is known to be the underlying cause of this lesion and also underlies cervical cancer, an AIDS-defining cancer, and anal cancer, a non-AIDSdefining cancer. The incidence of these lesions has not been affected by the use of ARVs. A possible explanation may be that HAART has largely eliminated giant condyloma acuminatum, a clinically benign tumor. This is conceivable, given the biological differences between giant condyloma acuminatum and squamous cell carcinoma. Under-reporting of cases on giant condyloma acuminatum with underlying HIV/AIDS is the other possible explanation for the paucity of literature on this rare condition. ${ }^{16}$

Patients infected with the human immunodeficiency virus (HIV) may require surgery to treat in- 
fections and diseases associated with the condition. HIV infects white blood cells called $\mathrm{CD}_{4}$ cells. Since white blood cells are the main component of the immune system, HIV patients have an increased risk of developing infections. With the introduction of HAART, a combination of anti-HIV drugs, HIV patients are able to live longer. As a result, it is possible for HIV patients to require surgical interventions for long-term conditions. Common surgical complications include bleeding, infections, and nerve damage. It has been suggested that HIV patients may have an increased risk of surgical complications (especially infections) because their immune systems have weakened. However, there is currently no scientific data on the prevalence of surgical complications between HIV patients and non-infected patients. ${ }^{13}$

Researchers believe that the risks of surgical complications for HIV patients can be predicted in a way similar to the method used in HIV-negative patients. Prior to surgery, healthcare providers should perform a physical examination, detailed medical history, and laboratory testing to determine the patient's overall health. Healthcare providers must also consider possible interactions between the patient's anti-HIV drugs (antiretrovirals) and medications, such as pain relievers, that are used before, during, and after surgical procedures. It remains unclear whether a patient's $\mathrm{CD}_{4}$ cell count influences their risk of surgical complications. Healthy individuals have a $\mathrm{CD}_{4}$ cell count between 600 and 1,200 cells per microliter of blood. The lower the $\mathrm{CD}_{4}$ count, the weaker the patient's immune system. Some studies have found no correlation between low $\mathrm{CD}_{4}$ cell counts and surgical complications, while others have found an increase in complications affected by lower $\mathrm{CD}_{4}$ counts. Further research is needed before a firm conclusion can be made.

Treatment for surgical complications depends on the underlying cause, as well as the patient's overall health and age. Patients should tell their healthcare providers if they are taking any other drugs (prescription or over-the-counter), herbs, or supplements because they may interact with the treatment. Medications called antimicrobials are used to treat infections that develop after surgery. Antibiotics are used to treat bacterial infections, antifungals are used to treat fungal infections, and antivirals are used to treat viral infections. The exact dose and duration of treatment depends on the type and severity of the infection, as well as the overall health of the patient. Patients can help prevent surgical complications from occurring. Before surgery, patients should follow the instructions from their healthcare providers on how to care for their wounds after surgery. Surgical wounds should be kept clean and monitored for signs of infection (e.g. swelling, reddening, pain). ${ }^{13}$

Radiochemotherapy, topical and intra-lesional chemotherapy, carbon dioxide laser therapy, Wide surgical excision, and photodynamic therapy have all been used in different combinations in the treatment of giant condyloma acuminatum, with varying success results. ${ }^{17}$ The successful use of neo-adjuvant chemoradiotherapy to down-size a tumor with subsequent complete surgical excision was reported. The administration of an autogenous vaccine after surgical excision has the lowest recurrence rates ever reported in one year (less than 5\%). ${ }^{18}$ There is a risk of transformation of a giant condyloma acuminatum into an aggressive squamous cell carcinoma ( $30 \%$ to $56 \%$ over five years), in addition to a $10 \%$ risk of anaplastic transformation after radiotherapy. 9,15

Although podopyhyllin and laser could be applied for treatment in general condyloma acuminatum, but for giant condyloma acuminatum, the most reliable method, as being performed on our patients, is still electrocautery excision. 5,19,20

For our patient, surgery remains the most effective mode of management. In this paper, case 2 was reported as one of our experience. Although the second case patient is without HIV, but the second case inspired us for the first case.

Post-operatively, our patient was able to ambulate and perform a number of activities of daily living; the foulsmelling exudated and pain was gone. Electrocautery excision is the primary mode of treatment of giant condyloma acuminatum. Some literature state that recurrence rates of $50 \%$ have been reported. ${ }^{9}$ The patient's improved nutritional status and motivation may warrant a revision of the original intent of the surgery, subject to the patient's consent to allow an aggressive surgical excision. There is as yet no evidence of the efficacy of immunosuppressive therapy administered to patients with AIDS receiving ARV therapy. Certainly the emerging or unusual presentations of surgical pathology secondary to HIV/AIDS offer a challenge and indicate the need to establish guidelines on the use of chemotherapeutic agents, in addition to ARVs, for this patient population. ${ }^{21,22}$ 


\section{CONCLUSION}

Although the giant Condyloma Acuminatum is combined with HIV, but the management is not as difficult as imagined because the tumor's base is not wide, but shaped like inverted mushroom and it is not necessary to do local flap reconstruction.

Electrocautery excision without local flap reconstruction significantly improved the life quality of the patient presented here.

\section{REFERENCES}

1. Creasman C, Haas PA, Fox TA Jr, Balazs M. Malignant transformation of anorectal giant condyloma acuminatum (Buscke-Loewenstein tumor). Dis Colon Rectum 1989; 32: 481- 7.

2. Bertram P, Treutner KH, Rubben A, et al. Invasive squamous cell carcinoma in giant anorectal condyloma (BusckeLoewenstein tumor). Langenbecks Arch Chir 1995; 380: 115-8.

3. McKee PH: Infectious Diseases, in McKee PH (Ed): Pathology of the Skin with Clinical Correlations, Barcelona, Times Mirror International Publishers, 1996, $2^{\text {nd }}$ ed, 4.1-4.91.

4. Kibrite A, Zeitouni NC, Cloutier R. Aggressive giant condyloma acuminatum associated with oncogenic human papilloma virüs: A case report. Can J Surg 1997; 40: 43-5.

5. Ergun SS, Kural YB, Buyukbabani N, Verim L, Akbulut H, Gurkan L. Giant condyloma acuminatum. Dermatol Surg 2003; 29: 300-3.

6. Bogomoletz WV, Potet F, Molas G. Condylomata acuminata, giant condyloma acuminatum (Buschke-Lowenstein tumor) and verrucous squamous carcinoma of the perianal and anorectal region: A continuous precancerous spectrum? Histopathology 1985; 9: 155-69.

7. Anderson VM, Savage EW, Chapman GW, Prater WF. Giant condyloma acuminatum of the endocervix and lower uterine segment. J Reprod Med 1979; 23: 46-8.

8. Norris CS. GCA (Buscke-Loewenstein tumor) involving a pilonidal sinus: A case report and review of the literature. J Surg Oncol 1983; 2: 47-50.

9. Gholam P, Enk A, Hartschuh W. Successful surgical management of giant condyloma acuminatum (Buschke-Löwenstein tumor) in the genitoanal region: a case report and evaluation of current therapies. Dermatology 2009, 218:56-9.
10. Meli BG, Ramos H, Gomez LAD. Giant condyloma acuminatum (Buschke- Loewenstein tumour) of the scrotum. Eur J Plast Surg 1994, 17:43-7.

11. Sepou A, Zoguereh DD. [Giant anovulvar condyloma acuminata revealing HIV-1 seropositivity in a Centrafrican patient] [in French]. Med Trop (Mars) 1998, 58:378-80.

12. Granados E, Palou J, Rios G, Vicente J. Urologic pathology in patients positive for anti-HIV antibodies. Actas Urol Esp 1989, 13:378-80.

13. Carrozza PM, Merlani GM. CO(2) laser surgery for extensive, cauliflower-like anogenital condylomata acuminata: retrospective long-term study on 19 HIV-positive and 45 HIVnegative men. Dermatology. 2002;205(3):255-9.

14. Googe PB, Chung SJ, Simmons J, King R, Giant - Sized Condyloma of the breast with focal acantholytic changes, J Cutan pathol, 2000, 27: 319-22

15. Garazzino S, Canavese F, Coppo P, Cortese MG, Pucci A, Mignone F, Tovo PA. An infant presenting with a voluminous exophytic perineal mass. Pediatr Infect Dis J 2010, 29:57783.

16. Landin L, Rodriguez-Perez JC, Garcia-Bello MA, Cavadas PC, Thione A, Nthumba P, Blanes M, Ibañez J. Kidney transplants in HIV-positive recipients under HAART: a comprehensive review and meta-analysis of 12 series. Nephrol Dial Transplant 2010, 9:3106-15.

17. Tytherleigh MG, Birtle AJ, Cohen CE, Glynne-Jones R, Livingstone J, Gilbert J. Combined surgery and chemoradiation as a treatment for the Buschke-Löwenstein tumour. Surgeon 2006, 4:378-83.

18. Wiltz $\mathrm{OH}$, Torregrosa M, Wiltz O. Autogenous vaccine: the best therapy for perianal condyloma acuminata? Dis Colon Rectum 1995, 38:838-41.

19. Parise P, Sarzo G, Finco C, Marino F, Savastano S, Merigliano S. Giant condyloma acuminatum of the anorectum (BuschkeLowenstein tumor): A case report of conservative surgery. Chir Ital 2004; 56: 157-61.

20. Mestrovic T, Cavcic J, Martinac P, Turcic, Zupancic B, Cavcic AM, Jelincic Z. Reconstruction of skin defects after radical excision of anorectal giant condyloma acuminatum: 6 cases. JEADV 2003; 17: 541-5.

21. Govender PS. Atypical presentation of angiosarcoma of the scalp in the setting of human immunodeficiency virus (HIV). World J Surg Oncol 2009, 7:99.

22. Nthumba PM. Giant pyogenic granuloma of the thigh: a case report. J Med Case Reports 2008, 2:95. 